tropical sun, the black lizards being therefore most conspicuous. Prof. Peters, of Berlin, to whom some years ago I sent specimens of these reptiles, called them in one of his letters. Cnemidophorus nigricolor, but as I am not aware of his having published this name, I believe he got soon convinced of its true character as a melanotic variety. I may be allowed to add that I have mentioned this case already in my "Estudios sobre la Flora y Fauna de Venezuela" (Caracas, r 877 ), pp. 28o, 28r, when I also pointed out the difficulty of its explanation by the "struggle for existence " theory.

Caracas, May I5

\section{Intellect in Brutes}

I. TIIE following case was witnessed by my friend Dr. Rafael Villavicencio, of Caracas, during his stay last year in the town of Ponce, in the Island of Portorico:-

The little river in the neighbourhood of the town bad risen, in consequence of heavy rains, and ran with rather considerable swiftness. In a certain place it is crossed by a road, where it was forded by a countryman sitting on his mule cart. His dog swam after him, but was taken down by the current and carried back to the bank. Then, after a moment's hesitation, the animal ran some distance up the bank, jumped into the water, and managed to reach the other side just where the road emerged from the river, acting thus precisely as a boatman might have done in similar circumstances.

2. To my friend Dr. Velasquez Level, a respectable physician of this city, and for several years a resident of the Island of Margarita, I am indebted for the following tonching instance of the sagacity of a bitch. Her owner, for some reason or other, had destroyed all the female puppies in two successive litters. On her having brought forth a third one it was found that there were but three male puppies. The bitch, however, was observed to leave her whelps occasionally, and to return some time after. Jeing followed, she was discovered suckling three female puppies, which she had hidden under some brushwood, undoubtedly with the intention of saving them from the master's cruel hands. This case happened in a small place, called Juan Griego, on the northern side of the island.

A. ERNSI

Caracas, May I5

\section{Intellect in Brutes-a Cat and a Mirror}

MANy years ago at Carne farmhouse, where relatives of mine were then living, the household cat was observed to enter a bedroom in course of being spring-cleaned.

The looking.glass being on the floor the cat on entering was confronted with its own reflection and naturally concluded that he saw before him a real intruder on his domain.

Hostile demonstrations were the result, followed by a rush to the mirror and then meeting an obstacle to his vengeance, a fruitless cut round to the rear. This mancuvre was more than once repeated with of course equal lack of success. Finally the cat was seen to deliberately walk up to the looking-glass lieeping its eyes on the image, and then when near enough to the edge, to feel carefully with one paw behind, for the supposed intruder whilst with its head twisted round to the front it assured itself of the persistence of the reflection.

The result of this experiment fully satisfied the cat that he had been the victim of delusion and never after would he condescend to notice mere reflections, though the trap was more than once laid for him.

Thos. B. GROVES

\section{Butterfly Swarms}

EVEN your varied correspondence from all parts of the world has rarely furmished us with such a wonderfully complete and interesting personal observation as that of $\mathrm{Mr}$. Sydney B. J Slierichly (NATURE, vol. xx. p. 266) on the West African brecding-grounds of Vanessa cardut, and the almost mechanical jumplise and simultaneity with which such a swarm as that which he descrilies free themaselves from the pupa-case and set forth on their migration. Can any one throw a similar light on the periodicily of Colias edusa? $V$. cardui is a more constant insect in this neirbbourbood than any other with which $\mathrm{I}$ am accuainted; but the numbers in June of this year were quite unusual. Also we remarked that they were very high-coloured and vigorous, mlike the ordinary washed ont hybernated specimens of early summer. As one of your correspondents has

remarked of his neighbouthood, so here $C$. edusa swarmed in 1877. It was the prevailing insect. In 1878 we had bardly a solitary example. The so-called $C$. helice-the pale variety of $C$ edusa-was frequent in 1877 . I saw none of $C$. Iryale; in. deed, have never seen that insect here. HENRY CECIL Bregner, Bournemouth

\title{
REPORT OF AN UNUSUAL PHENOMENON OBSERVED AT SEA
}

THE following Report to the Admiralty has been communicated to us for publication by Capt. Evans, C.B., F.R.S., the Hydrographer to the Navy :-

\section{H.M.S. Vulture, Bahrein, May 17, 1879}

SIR, - I have the honour to inform you that, at about 9.40 P.M. on May 15 , when in lat. $26^{\circ} 26^{\prime} \mathrm{N}$. and long. $53^{\circ}$ I $1^{\prime}$ E., a clear, unclouded, starlight night, Arcturus being within some $7^{\circ}$ of zenith, and Venus about to set; wind north-west, force 3 , sea smooth, with slight swell from the same direction; ship on starboard tack, heading west-south-west and going three knots, an unusual phenomenon was seen from the vessel.

I noticed luminous waves or pulsations in the water, moving at great speed and passing under the ship from the south-south-west. On looking towards the east, the appearance was that of a revolving wheel with centre on that bearing, and whose spokes were illuminated, and looking towards the west a similar wheel appeared to be revolving, but in the opposite direction. I then went to the mizen top (fifty feet above water) with the first lieutenant, and saw that the luminous waves or pulsations were really travelling parallel to each other, and that their apparently rotatory motion, as seen from the deck, was caused by their high speed and the greater angular motion of the nearer than the more remote part of the waves. The light of these waves looked homogeneous, and lighter, but not so sparkling, as phosphorescent appearances at sea usually are, and extended from the surface well under water; they lit up the white bottoms of the quarter-boats in passing. I judged them to be twenty-five feet broad, with dark intervals of about seventy-five between each, or Ioo from crest to crest, and their period was seventy-four to seventy-five per minute, giving a speed roughly of eighty-four English miles an hour.

From this height of fifty feet, looking with or against their direction, I could only distinguish six or seven waves; but, looking along them as they passed under the ship, the luminosity showed much further.

The phenomenon was beautiful and striking, commencing at about $6 \mathrm{~h} .3 \mathrm{~m}$. Greenwich mean time, and lasting some thirty-five minutes. The direction from which the luminous waves travelled changed from southsouth-west by degrees to south-east and to east. During the last five minutes concentric waves appeared to emanate from a spot about 200 yards east, and these meeting the parailel waves from south-east did not cross, but appeared to obliterate each other at the moving point of contact, and approached the ship, inclosing an angle about $00^{\circ}$. Soundings were taken in twenty-nine fathoms; Stiffe's Bank, with fifteen to twenty fathoms, being west about one mile. The barometer was already at $29^{\prime} 25$ from 8 to I2 P.M.

\section{Temperature of air}

Temperature of sea-water...

At 8 p.ns.

10.15 P...1. 83

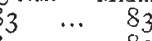

I cbserved no kind of change in the wind, the swell, or in any part of the heavens, nor were the compasses disturbed. A bucket of water was drawn, but was unfortunately capsized before darylight. The ship passed through oily-looking fish spawn on the evening of the I5th and morning of the rsth inst. - I have the honour to be, Sir, your obedient servant,

\section{J. Eliot Pringle, Commander}

